\title{
Rebastinib Tosylate
}

National Cancer Institute

\section{Source}

National Cancer Institute. Rebastinib Tosylate. NCI Thesaurus. Code C82693.

The tosylate salt of rebastinib, an orally bioavailable small-molecule inhibitor of multiple tyrosine kinases with potential antineoplastic activity. Rebastinib binds to and inhibits the Bcr-Abl fusion oncoprotein by changing the conformation of the folded protein to disallow lig and-dependent and lig and-independent activation; in addition, this agent binds to and inhibits Src family kinases LYN, HCK and FGR and the receptor tyrosine kinases TIE-2 and VEGFR-2. Rebastinib may exhibit more potent activity against T315I Bcr-Abl gatekeeper mutant kinases than other Bcr-Abl kinase inhibitors. The TIE-2 and VEGFR-2 receptor tyrosine kinases regulate angiogenesis, respectively, while the Src family kinases Abl, LYN, and HCK Src regulate a variety of cellular responses including differentiation, division, adhesion, and the stress response. 